\title{
EDUCATIF IMPLICATIONS OF THE INTERPRETATION OF OLDER TERMIN THE QUR'AN PERSPECTIVE
}

\section{IMPLIKASI EDUKATIF INTERPRETASI TERM DEWASA-TUA DALAM PERSPEKTIF AL-QUR'AN}

\author{
Rahendra Maya $^{1}$, Ulil Amri Syafri², Budi Heryanto ${ }^{3}$ \\ ${ }^{1}$ Dosen Tetap Prodi Pendidikan Agama Islam STAI Al Hidayah Bogor \\ ${ }^{2}$ Dosen Tetap Sekolah Pascasarjana Universitas Ibn Khaldun Bogor \\ ${ }^{3}$ Dosen Tetap Prodi Pendidikan Agama Islam STAI Al Hidayah Bogor \\ email: rahendra.maya76@gmail.com \\ ulamris@gmail.com \\ budihasmi2020@gmail.com
}

\begin{abstract}
This article examines the educatif impilcation of the older term in Qur'anic verses that express through the interpretation of the commentators in their various popular works that are authoritative using a thematic interpretation approach (al-tafsîr al-maudhô' $\hat{\imath})$ using qualitative methods of literature study with analysis descriptive-interpretative nature. The older term with various forms and derivations that were successfully identificated which later became the object and focus of this research were the term arba'in sanah, ardzal al'umur, al-shayb (al-syīb and al-shyaibah), al-shaykh (and al-syuyûkh), al-'ajûz, al-kibar (and al-kabîr), nu'ammir (yu'ammar and mu'ammar), and thâla or tathâwala al-'umur. After elaborating on the interpretation and accentation of its meaning and analyzing the results of the discussion, it turns out that these terms have many implications, especially those relating to aspects of Islamic education.
\end{abstract}

Keyword: implikasi edukatif, adult, old, thematic interpretation.

\section{ABSTRAK}

Artikel ini mengkaji impikasi edukatif dari interpretasi ayat-ayat tentang erm dewasa-tua melalui ayat-ayat Al-Qur'an yang mengungkapkan term dewasa-tua melalui interpretasi atau penafsiran para mufassir dalam berbagai karya populer mereka yang otoritatif dengan

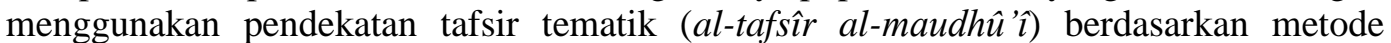
kualitatif studi literatur dengan analisis bersifat deskriptif-interpretatif. Term dewasa-tua dengan berbagai bentuk dan derivasinya yang berhasil diidentifikasi kemudian dijadikan objek dan fokus penelitian ini adalah term arba'în sanah, ardzal al-'umur, al-syaib (al-syîb dan al-syaibah), al-syaikh (dan al-syuyûkh), al-'ajûz, al-kibar (dan al-kabîr), nu'ammir (yu'ammar dan mu'ammar), dan thâlaltathâwala al-'umur. Setelah dielaborasi penafsiran dan aksentuasi maknanya serta dianalisis hasil pembahasannya, ternyata term-term tersebut memiliki banyak implikasi, terutama yang berkaitan dengan aspek pendidikan Islam.

Kata kunci: implikasi edukatif, dewasa, tua, tafsir tematik.

\section{A. PENDAHULUAN}

Dalam studi Al-Qur'an baik berdasarkan kajian klasik maupun dalam diskursus kontemporer, aspek kosakata atau term (lafzh) yang terdapat dan disebutkan dalam Al-Qur'an dapat dikategorikan sebagai salah satu kajian yang menarik. Dari kajian tersebut melahirkan disiplin ilmu yang kemudian dinyatakan sebagai dan berkembang menjadi tafsir linguistik (altafsîr al-lughawî), tafsir yang bercorak kebahasaan. Menurut Musâ'id Al-Thayyâr (1432 H.: 68-140), corak al-tafsîr al- 
lughawî tersebut terus berkembang pesat hingga membidani lahirnya dua model kajian utama yang berkaitan dengannya. Pertama model penafsiran linguistik terhadap lafazh atau term Al-Qur'an (uslûb al-tafsîr al-lafzhî) yang umumnya didasarkan kepada ilmu-ilmu linguistik yang berkaitan dengan ilmu sintaksis (al-sharf), ilmu gramatikal-morfologis (al-nahw), dan ilmu retorika (al-balaghah, meliputi ilmu alma'ânî, al-bayân, dan al-badî') serta ilmuilmu kebahasaan lainnya (Al-Ghulâyainî, 1994: I/8); dan kedua model penafsiran linguistik secara homonim dan polisemi (uslûb al-wujûh wa al-nazhâ'ir) yang umumnya disandarkan pada 'ilm al-wujûh wa al-nazhâ'ir.

Di antara ayat yang dapat direnungkan (tadabbur) dan dikaji dengan kedua model pendekatan dari corak al-tafsîr al-lughawî adalah firman Allah berikut:

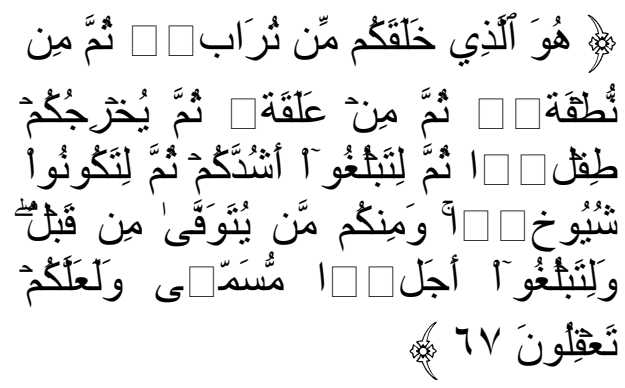

"Dialah yang menciptakanmu dari tanah kemudian dari setetes mani, lalu dari segumpal darah, kemudian kamu dilahirkan sebagai seorang anak, kemudian dibiarkan kamu sampai dewasa, lalu menjadi tua. Tetapi di antara kamu ada yang dimatikan sebelum itu. (Kami perbuat demikian) agar kamu sampai kepada kurun waktu yang ditentukan, agar kamu mengerti."

\section{(Q.S. Al-Mu'min [40]: 67)}

Ungkapan deskriptis yang hampir identik dengan Q.S. Al-Mu'min [40]: 67 terdapat pula dalam Q.S. Al-Haj] [22[: 5 dan Al-Mu'minûn [23]: 12-16. Di antara kesimpulan yang dapat diambil dari ayat- ayat tersebut adalah deskripsi tentang tahapan atau fase penciptaan manusia (emriologi) dengan menggunakan term (lafzh) tertentu yang identik sama maupun berbeda, yang memiliki aksentuasi makna tertentu (al-dilâlah) yang ingin ditunjukkan olehnya (madlûl) (Anîs, 1976), dimana term (al-lafzh) tersebut beserta susunan kata lainnya yang menjadi kalimat utuh dalam ayat merupakan sebuah bentuk kemukjizatan Al-Qur'an (Syâkir, 1992). Yaitu dimulai dengan diciptakan dari tanah (al-turâb) melalui bapak moyangnya, Adam. Kemudian dari setetes mani (al-nuthfah) lalu menjadi segumpal darah ('alaqah). Setelah itu dilahirkan dalam wujud anak (al-thifl). Akhirnya ada yang tumbuh menjadi dewasa (al-balîgh, bulûgh al-asyudda) dan ada pula yang sampai berusia tua (al-syaikh) sebelum kemudian meninggal dunia.

Term-term popular seperti al-nuthfah, al-'alaqah, dan al-mudhghah serta beberapa term lainnya yang berkaitan langsung dengan embriologi banyak dijadikan kajian termasuk dalam artikel jurnal. Term lainnya yang juga banyak dikaji adalah proses tumbuh-kembang manusia, antara lain term al-thifl (anak, atau anak kecil), almurâhaqah (remaja), al-fatâ wa al-syabâb (pemuda), dan al-balîgh wa bulûgh alasyudda (baligh, akil baligh, atau mencapai kedewasaan), serta term dewasa dan bahkan fase lanjut usia (lansia).

Kajian tentang al-nuthfah, al-'alaqah, al-mudhghah, dan term lainnya yang terkait dengan embriologi dan proses tumbuh kembang manusia umumnya dikaji dalam diskursus tafsir ilmiah atau tafsir saintis ( $a l$ tafsîr al-'ilmî), atau sebagai studi tentang kemukjizatan ilmiah dalam Al-Qur'an (almu'jizah al-'ilmiyyah fî Al-Qur'ân). Kajian tersebut antara lain dilakukan oleh Zakir Naik (2015: 57-69), 'Imâd Zakî Al-Bârûdî (t.t.: 92-111), dan Yûsuf Al- $\underline{H a ̂ j j ~ A h m a d ~}$ (2016); serta terdapat dalam anotasi penjelasan (syarh ) hadits yang keempat dari kitab Al-Arba'în Al-Nawawiyyah (Sulthân, 
1991; Âlu Al-Syaikh: 2010; dan Yusrî, 2009) yang populer.

Abdul Mustaqim (2019: 349-382) menulis artikel jurnal dan menyatakannya sebagai sebagian dari hasil risetnya sebagai dosen; mengkaji tentang anak yang disebutkan dalam Al-Qur'an dengan menggunakan term al-walad, al-thifl, al-ibn, al-bint, al-dzurriyyah, al-hafadah, al-shabî, dan al-ghulâm serta berbagai aksentuasi dan implikasi maknanya. Sedangkan penelitian Hanân 'Athiyyah Al-Thaurî Al-Juhnî dalam Tesis Magisternya (2001) yang kemudian dipublikasikan menjadi buku ilmiah populer, walaupun tidak secara langsung mengkaji term al-thifl, telah membahas tentang fase kanak-kanak (marhalah althufûlah) dalam pendidikan remaja muslimah.

Di samping penelitian di atas, Hanân Al-Juhnî juga telah melakukan kajian tentang fase remaja (marhalah almurâhaqah) sebagai bagian dari Tesis Magisternya dan merupakan lanjutan dari penelitiannya, walaupun tidak mengungkap term remaja (al-murâhaqah) secara implisit.

Muhammad Anshori (2016: 227-251), Misbahul Wani (2019: 71-94), dan Khairul Amin (2017) melakukan kajian tentang pemuda melalui beberapa term yang mengindikasikannya, antara lain melalui term al-fatâ dan al-fityah serta term al-syâb dan al-syabâb. Kajian semisal tentang fase kedewasaan dengan menggunakan term balagha asyuddah, balaghû al-nikâh, dan kahlan juga telah dilakukan oleh Nuryadin (2014).

Jejen Zainal Mutaqin (2017) dan Tim Lajnah Pentashihan Mushaf Al-Qur'an melakukan kajian tentang lanjut usia (lansia) dengan sama-sama mengkaji term al-syaikh, al-kibar, al-'ajuz, dan ardzal al-'umur, serta sedikit mengkaji tentang term thâla al'umur.

Ada pula kajian yang dilakukan oleh 'Abd Al-Karîm Ibrâhîm Shâlih (2016) yang mengelaborasi term lelaki (al-rajul) dan beberapa bentuk derivasinya untuk kemudian dielaborasi berbagai implikasi makna kelelakiannya (ma'âlim al-rajûlah) dari perspektif wawasan keislaman. Sedangkan Wafâ' bint 'Abd Al-'Azîz Suwailim (2013) menulis Tesis Magister tentang ibu (al-umm) yang kemudian diterbitkan menjadi buku popular dengan judul Ahkâm Al-Umm fî Al-Fiqh Al-Islâmî.

Di samping itu, ada pula penelitian doktoral yang telah dilakukan oleh Rosidin (2013) dan Mohammad Al Farabi (2018) tentang pendidikan orang dewasa (andragogy) berdasarkan ayat-ayat AlQur'an yang berkaitan dengan model pendidikan andragogi tersebut, namun tidak secara spesifik membahas ayat-ayat tentang term dewasa.

Dalam artikel ini term yang hendak dikaji secara khusus berdasarkan interpretasi para mufassir dan dilaborasi implikasinya adalah term dewasa-tua yang dapat diidentifikasi dari dan sebagai gabungan dari dua term, yaitu term dewasa khususnya dewasa akhir (late adults) dan term umur tua yang meliputi tiga kategorinya (olderly, old, dan very-old). Term dewasa-tua yang dimaksud dalam penelitian artikel ini adalah dimulai dari usia 40 tahun hingga umur sangat tua melebihi usia 90 tahun atau hingga sebelum seseorang meninggal dunia melalui kematiannya.

Oleh karena itu, artikel ini akan mengkaji term dewasa-tua berdasarkan penyebutannya dalam ayat-ayat Al-Qur'an secara tematis (maudhû' $\hat{\imath}$ ) sebagai data awal, dielaborasi maknanya berdasarkan penafsiran para mufassir yang telah diakui otoritas kepakarannya sebagai sumber data primer, dan berdasarkan sumber-sumber sekunder yang berkaitan kemudian dikemukakan berbagai implikasinya secara kualitatif dengan analisis yang bersifat deskriptif-interpretatif. 


\section{B. METODE PENELITIAN}

Jenis penelitian yang digunakan dalam artikel ini adalah menggunakan penelitian kualitatif dengan pendekatan kepustakaan atau studi literatur (library research), dengan menggunakan bahan-bahan pustaka dan literatur terkait dengan tema judul sebagai sumbernya, baik primer maupun sekunder, terutama sumber dari jurnal, prosiding, penelitian ilmiah-akademik, buku ilmiah, dan lainnya.

Dalam penelitian ini digunakan pula teknik penafsiran al-tafsîr al-maudhû'î untuk menafsirkan ayat-ayat yang berkaitan dengan term dewasa-tua dan juga metode $a l$ tafsîr al-tarbawî untuk menafsirkan ayatayat tersebut dalam perspektif pendidikan Islam (tarbawî).

Sedangkan
menggunakan
metode $\begin{array}{r}\text { datanya } \\ \text { deskriptif- }\end{array}$
interpretatif. Yaitu dengan mendeskripsikan term dewasa-tua dan penafsiran ayat-ayat tentangnya kemudian dilakukan interpretasi penafsiran terhadap ayat-ayat tersebut berdasarkan kajian para mufassir dan menginterpretasi implikasi edukasinya.

Oleh karena itu, berdasarkan metode penelitian yang telah dikemukakan dapat dijelaskan langkah-langkah penelitian dalam artikel ini sebagai berikut:

1. Menetapkan tema dan judul artikel, yaitu tentang term dewasa-tua dalam Al-Qur'an, interpretasinya, dan implikasi edukatifnya.

2. Menelusuri studi atau kajian pustaka yang memiliki signifikansi langsung dan tidak langsung dengan tema kajian yang telah dilakukan sebelumnya.

3. Mengidentifikasi ayat-ayat tentang term dewasa-tua secara maudhû' $\hat{\imath}$.

4. Menafsirkan ayat-ayat tentang term dewasa-tua tersebut berdasarkan penafsiran atau interpretasi para mufassir otoritatif dan populer, baik mufassir klasik maupun mufassir kontemporer.

5. Menginterpretasi penafsiran para mufassir tentang term dewasa-tua tersebut berdasarkan kajian pendidikan Islam (tarbawî).

6. Menemukan implikasi edukatif dari term dewasa-tua yang terdapat dalam Al-Qur'an berdasarkan interpretasi para mufassir yang telah dideskripsikan sebelumnya.

\section{TINJAUAN TEORITIS}

\section{Term Dewasa-Tua}

Sebagaimana yang telah dikemukakan, bahwa yang dimaksud dengan term dewasatua dalam penelitian artikel ini adalah usia yang dimulai semenjang seseorang berumur 40 tahun hingga umur sangat tua antara lain melebihi usia 90 tahun atau hingga kematiannya.

Dalam Kamus Besar Bahasa Indonesia (2013: 323), dewasa berarti 1) sampai umur, akil baligh (bukan kanak-kanak atau remaja lagi); 2) telah mencapai kematangan kelamin, dan 3) matang (tentang pikiran, pandangan, dan sebagainya). Sedangkan term tua diartikan sebagai 1) sudah lama hidup, lanjut usia (tidak muda lagi); 2) sudah lama (lawan baru); 3) sudah masak atau sampai waktunya untuk dipetik (tentang buah-buahan dan sebagainya); 4) sudah mendidih atau sudah masak benar (tentang air, minyak, dan sebagainya); 5) kehitamhitaman atau sangat (tentang warna); 6) tinggi mutunya, jadi banyak tulennya (tentang emas); dan 7) pemimpin (yang dipandang tua, berpengetahuan, dan berpengalaman), kepala (2013: 1489).

Sementara itu, berdasarkan makna definitif dan substansial dimensi psikologisnya, usia dewasa sendiri dapat dibedakan dalam tiga kategori, yaitu dewasa awal (early adults) dari usia 16 sampai 
dengan 20 tahun, dewasa tengah (middle adults) dari 20 sampai 40 tahun, dan dewasa akhir (late adults) dari 40 hingga 60 tahun (Al Farabi, 2018: 31). WHO kemudian membagi umur tua menjadi tiga bagian, yaitu umur lanjut usia (olderly) dari 60-70 tahun, umur tua (old) dari 70-90 tahun, dan umur sangat tua (very-old) yang berusia $>90$ tahun (Lajnah Pentashihan Mushaf, 2012: 137). Walaupun di kemudian hari terdapat pergeseran kategorisasi umur dan banyak pula pendapat yang mengemukakannya, dalam artikel hal ini diharapkan tidak perlu diperdebatkan lebih lanjut.

Oleh karena itu, ketika digabungkan menjadi term dewasa-tua, maka dapat didefinisikan sebagai orang yang sudah melewati usia remaja dan telah mencapai usia matang baik secara fisik maupun psikis hingga berusia lanjut sebelum mengalami kematian.

\section{Term Dewasa-Tua dalam Al-Qur'an}

Berdasarkan definisi operasional tersebut dan sepanjang penelusuran dalam kitab Al-Mu'jam Al-Mufahras li Alfâzh AlQur'ân Al-Karîm karya Muhammad Fu'âd 'Abd Al-Bâqî (1988), Al-Mu'jam AlMaudhû' '̂ li Ayât Al-Qur'ân Al-Karîm karya Hanân 'Abd Al-Mannân (2000), Al-Dalîl AlMufahras li Alfâzh Al-Qur'ân Al-Karîm bi Hâsyiyah Al-Mushhaf Al-Syarîf karya Husain Muhammad Fahmî Al-Syâfi'î (2008), dan kitab Al-Mu'jam Al-Mufahras li Alfâzh Al-Qur'ân Al-Karîm Al-Syâmil bi AlRasm Al-'Utsmânî karya 'Abd Allah Ibrâhîm Jalghûm. (2015); dalam Al-Qur'an term dewasa-tua ini dapat diketahui dan diidentifikasi dari beberapa term yang terkait yang sepadan. Berikut hasil penelusuran dan identifikasinya:

\begin{tabular}{|c|l|l|l|}
\hline $\mathbf{N}$ & \multicolumn{1}{|c|}{ Term } & \multicolumn{1}{|c|}{ Surat - Ayat } & \multicolumn{1}{|c|}{$\begin{array}{c}\text { Makna } \\
\text { Umum }^{1}\end{array}$} \\
\hline 1 & $\begin{array}{l}\text { Arba'în } \\
\text { Sanah }\end{array}$ & $\begin{array}{l}\text { Al-Ahqâf [46]: } \\
15\end{array}$ & Umur 40 tahun \\
\hline 2 & & Al-Nahl [16]: 70 & \\
\hline
\end{tabular}

\begin{tabular}{|c|c|c|c|}
\hline & $\begin{array}{l}\text { Ardzal Al- } \\
\text { 'Umur }\end{array}$ & Al-Hajj [22]: 5 & $\begin{array}{l}\text { Umur paling } \\
\text { lemah, tua } \\
\text { renta (pikun) }\end{array}$ \\
\hline \multirow[t]{3}{*}{3} & Syaib & Maryam [19]: 4 & \multirow{3}{*}{$\begin{array}{l}\text { Beruban, usia } \\
\text { lanjut }\end{array}$} \\
\hline & Syîb & $\begin{array}{l}\text { Al-Muzammil } \\
\text { [73]: } 17\end{array}$ & \\
\hline & Syaibah & Al-Rûm [30]: 54 & \\
\hline \multirow[t]{4}{*}{4} & Syaikh & $\begin{array}{l}\text { Al-Qashash } \\
\text { [28]: } 23\end{array}$ & \multirow[t]{4}{*}{ Tua, lanjut usia } \\
\hline & & Hûd [11]: 72 & \\
\hline & & Yûsuf [12]: 78 & \\
\hline & Syuyûkh & $\begin{array}{l}\text { Al-Mu'min [40]: } \\
67\end{array}$ & \\
\hline \multirow[t]{4}{*}{5} & \multirow[t]{4}{*}{ 'Ajûz } & Hûd [11]: 72 & \multirow{4}{*}{$\begin{array}{l}\text { Perempuan } \\
\text { berusia tua }\end{array}$} \\
\hline & & $\begin{array}{l}\text { Al-Dzâriyât } \\
\text { [51]: } 29\end{array}$ & \\
\hline & & $\begin{array}{l}\text { Al-Syu'arâ' } \\
\text { [26]: } 171\end{array}$ & \\
\hline & & $\begin{array}{l}\text { Al-Shâffât [37]: } \\
135\end{array}$ & \\
\hline \multirow[t]{8}{*}{6} & \multirow[t]{6}{*}{ Al-Kibar } & $\begin{array}{l}\text { Al-Baqarah [2]: } \\
266\end{array}$ & \multirow[t]{8}{*}{$\begin{array}{l}\text { Masa tua, usia } \\
\text { lanjut }\end{array}$} \\
\hline & & $\begin{array}{l}\text { Âli 'Imrân [3]: } \\
40\end{array}$ & \\
\hline & & Ibrâhîm [14]: 39 & \\
\hline & & Al-Hijr [15]: 54 & \\
\hline & & Al-Isrâ' [17]: 23 & \\
\hline & & Maryam [19]: 8 & \\
\hline & \multirow[t]{2}{*}{ Kabîr } & $\begin{array}{l}\text { Al-Qashash } \\
\text { [28]: } 23\end{array}$ & \\
\hline & & Yûsuf [12]: 78 & \\
\hline \multirow[t]{4}{*}{7} & Nu'ammir & Fâthir [35]: 37 & \multirow{4}{*}{$\begin{array}{l}\text { Umur yang } \\
\text { dipanjangkan }\end{array}$} \\
\hline & & Yâsîn [36]: 68 & \\
\hline & \multirow{2}{*}{$\begin{array}{l}\text { Yu'ammar } \\
\text { (dan } \\
\text { Mu'amma } \\
\text { r) }\end{array}$} & $\begin{array}{l}\text { Al-Baqarah [2:] } \\
96\end{array}$ & \\
\hline & & Fâthir [35]: 11 & \\
\hline \multirow[t]{2}{*}{8} & $\begin{array}{l}\text { Thâla Al- } \\
\text { 'Umur }\end{array}$ & $\begin{array}{l}\text { Al-Anbiyâa [21]: } \\
44\end{array}$ & \multirow[t]{2}{*}{ Panjang umur } \\
\hline & $\begin{array}{l}\text { Tathâwala } \\
\text { Al-'Umur }\end{array}$ & $\begin{array}{l}\text { Al-Qashash } \\
\text { [28]: } 45\end{array}$ & \\
\hline
\end{tabular}

Bila term arba'în sanah, ardzal al'umur, al-syaib (al-syîb dan al-syaibah), alsyaikh (dan al-syuyûkh), al-'ajûz, al-kabîr (dan al-kibar), fi'il nu'ammir (yu'ammar dan isim mu'ammar), dan term thâla/tathâwala al-'umur diperhatikan dengan seksama, maka ke delapan term tersebut menunjukkan dan mengindikasikan term dewasa-tua sebagaimana yang dimaksud dalam penelitian.

Dari berbagai penelitian dan kajian sebelumnya dapat diketahui beberapa term yang telah dijadikan fokus pembahasan, 
yaitu term ardzal al-'umur, al-syaikh, al'ajûz, al-kabîr, dan thâla/tathâwala al'umur. Sedangkan term yang belum banyak mendapatkan perhatian sebagai objek dan fokus penelitian dalam artikel jurnal sejauh penelusuran adalah term arba'în sanah, alsyaib, dan fi 'il nu'ammir dan yu'ammar (dan mu'ammar), serta term thâla/tathâwala al'umur secara mendalam.

Term arba'în sanah sebenarnya telah mendapatkan atensi dan menjadi objek pembahasan dalam beberapa buku populer, antara lain oleh Anas Ahmad Karzûn dalam karyanya yang berjudul Wa Balagha Arba'în Sanah (1999 dan 2009), Muhammad Mûsâ Al-Syarîf (2003 dan 2017) yang berjudul Jaddid Hayâtaka: Risâlah ilâ Man Jâwaza Al-Arba'în dan 'Alî ibn Sa'îd ibn Da'jam dalam Yâ Ibn Al-Arba'în (2016). 'Alî ibn Sa'îd ibn Da'jam (2019) juga memiliki buku yang membahas tentang lansia yang berumur 60 tahun ke atas dengan judul $Y \hat{a}$ Shâhib Al-Sittîn.

\section{PEMBAHASAN}

\section{Interpretasi Term Dewasa-Tua}

Berikut interpretasi penafsiran dan aksentuasi makna dari berbagai term dewasa-tua yang dipergunakan oleh dan terdapat dalam Al-Qur'an berdasarkan kitab-kitab tafsir otoritatif yang populer sebagai sumber primernya dan sumbersumber sekunder lain yang mendukung.

\section{Term Arba'în Sanah}

Al-Qur'an menyebutkan term arba'în sanah hanya sekali, yaitu dalam Q.S. AlAhqâf [46]: 15. Maksud dari arba'în sanah adalah seseorang yang berumur 40 tahun; dimana interpretasi ini merupakan pendapat mayoritas atau bahkan hampir sebagai konsensus (ijmâ') dari ulama tafsir (mufassir).

'Abd Al-Rahmân Al-Sa'dî (2000: 781) berkesimpulan bahwa umur 40 tahun adalah masa yang dilalui seseorang setelah melewati fase dewasa (balagha alasyuddah) dengan telah berhasil meraih pencapaian maksimal dalam kekuatan fisik, vitalitas masa muda yang energik, dan puncak kesempurnaan rasionalitas akal (nihâyah quwwatihi wa syabâbihi, wa kamâl 'aqlihi). Usia dewasa (balagha al-asyuddah) ini menurutnya berkisar antara usia 30-33 tahun yang banyak diklaim sebagai masa emas (golden age).

Ada pula mufassir yang menyatakan bahwa golden age (balagha asyuddah) dimulai dari umur 30 atau 33 tahun dan berakhir pada umur 40 tahun (AlKhawârizmî, 2016: IV/174; dan Al-Farrâ‘, 2017: II/259); sehingga konon tidak ada seorang nabi yang diutus Allah sebagai utusan-Nya kecuali setelah berusia lebih dari 40 tahun (Al-Khawârizmî: IV/174; dan AlBaidhâwî, 2018: IV/217); karena usia 40-an merupakan batas usia bagi seseorang untuk menapaki tangga kesalehan dalam kebaikan dan untuk meniti kemuliaan kepribadian dalam kebajikan atau kebijaksanaan (hadd li al-insân fì shalâhihi wa najâbatihi) (AlAndalusî, 2007: VII/619).

Sedangkan Ibn Katsîr (1999: VII/280) berpendapat bahwa ketika seseorang berada dalam usia 40 tahun, maka sempurnalah akal, pemahaman, dan kelemah-lembutan atau kemurahannya (tanâha 'aqluhu wa kamula fahmuhu wa hilmuhu).

Dalam hal ini Allah berfirman:

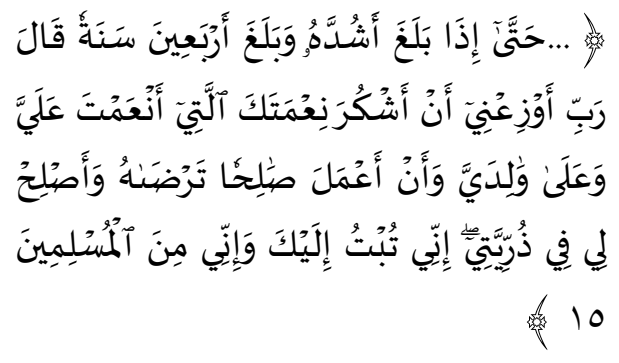

“...sehingga apabila dia (anak itu) telah dewasa dan umurnya sampai empat puluh tahun ia berdoa, "Wahai Tuhanku, berilah aku petunjuk agar aku dapat mensyukuri nikmat-Mu yang telah 
Engkau limpahkan kepadaku dan kepada kedua orang tuaku, dan agar aku dapat berbuat kebajikan yang Engkau ridai; dan berilah aku kebaikan yang akan mengalir sampai kepada anak cucuku. Sungguh, aku bertaubat kepada Engkau, dan sungguh aku termasuk orang muslim." (Q.S. Al-Ahqâf

\section{[46]: 15)}

Dari Q.S. Al-Ahqâf [46]: 15 dan interpretasi penafsirannya dapat diketahui bahwa ketika seseorang telah memasuki masa dewasa-tua dengan berusia 40 tahun, maka sangat dianjurkan untuk melakukan hal-hal berikut, yaitu a) berdoa untuk selalu mengingat berbagai nikmat yang telah dianugerahkan, b) beramal saleh yang mengandung dan mengundang keridaan, c) berdoa dan berharap serta berusaha dengan penuh kesadaran agar dianugerahkan anak keturunan yang saleh melalui upaya maksimal (ishlâh $)$, d) bertobat, dan e) mengidentifikasi diri sebagai orang yang bertipologi muslim. Semua anjuran bagi orang yang berusia dewasa-tua karena telah memasuki umur 40 tahun dan implementasinya yang termaktub dalam ayat tersebut mengindikasikan kematangan seseorang, baik secara ukhrawi maupun duniawi, baik fisik maupun psikisnya.

Oleh karena itu, Al-Qurthubi (2006: XIX/197) mengingatkan bahwa ketika seseorang telah mencapai usia 40 tahun, ia harus dapat menyadari betapa besarnya nikmat yang telah Allah anugerahkan kepadanya dan kedua orang tuanya. Nikmat kepadanya berupa hidayah (al-hidâyah) atau berwujud kesehatan dan kebugaran (alshihhah wa al-'âfiyah). Sedangan nikmat kepada kedua orang tuanya antara lain berupa kasih-sayang dalam mendidiknya di kala kecil (bi al-tahannun wa al-syafaqah hattâ rabbânî shaghîran) atau berwujud kekayaan dan kemampuan dalam mengurusnya (bi al-ghinâ wa al-tsarwah).

\section{Term Ardzal Al-'Umur}

Term ardzal al-'umur dalam Al-Qur'an terulang sebanyak dua kali, yaitu dalam Q.S. Al-Nahl [16]: 70 dan Al-Hajj [22]: 5; yang berarti usia tua atau renta hingga mengalami kepikunan yang dikategorikan sebagai umur paling lemah.

Dalam hal ini Allah berfirman:

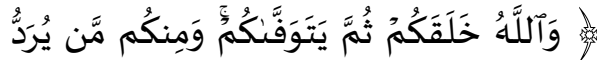

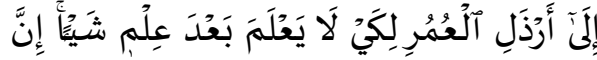

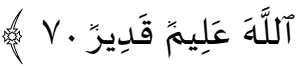

"Dan Allah telah menciptakan kamu, kemudian mewafatkanmu; di antara kamu ada yang dikembalikan kepada usia yang tua renta (pikun), sehingga dia tidak mengetahui lagi sesuatu yang pernah diketahuinya. Sungguh, Allah Maha Mengetahui lagi Maha Kuasa." (Q.S. Al-Nahl [16]: 70)

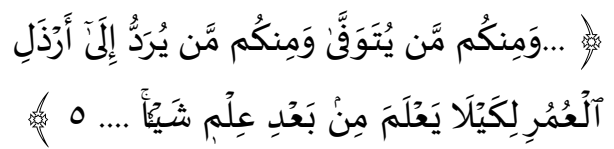
“...dan di antara kamu ada yang diwafatkan, dan (ada pula) di antara kamu yang dikembalikan sampai usia yang sangat tua (pikun), sehingga dia tidak mengetahui lagi sesuatu yang telah diketahuinya...." (Q.S. Al- $\underline{\text { Hajj }}$ [22]: 5)

Umur (al-'umur) sendiri secara literalmorfologis adalah term bagi masa makmur atau dinamisnya aktifitas fisik dalam kehidupan selama jasmani masih bernyawa, namun tidak menunjukkan adanya kontinuitas kelanggengan karena akan diakhiri oleh sebuah kematian (ism li muddah 'imârah al-badan bi al-hayâh dûna al-baqâ') (Al-Ashfahânî, t.t.: 347). Oleh karena itu, makna dari ardzal al-'umur (dewasa-tua) menurut Ibn Al-Jauzî (2002: 785) adalah sebagai usia paling buruk dan 
paling lemah (arda'uhu wa adwanuhu), dimana ada tiga pendapat dalam kisaran usianya yaitu umur 75, 90, dan umur 80 tahun. Bila disimpulkan kisaran usia dan rentang umurnya antara 75-90 tahun.

Dalam kedua ayat di atas, masa dewasatua hingga dalam usia renta (ardzal al'umur) akan berdampak pada pengetahuan kognitif yang pernah diketahuinya tidak akan dapat diketahui atau diingatnya kembali, alias mengalami kepikunan (demensia). Dalam realitas, walaupun ada orang yang tidak mengalami demensia, namun ternyata banyak pula orang yang mengalaminya.

Wahbah Al-Zuhailî (1996: 275) menjelaskan bahwa yang dimaksud usia dewasa-tua (ardzal al-'umur) sebagai usia yang paling buruk dan paling lemah karena dibarengi oleh demensia serta kelemahan dalam rasionalitas dan penurunan fungsi inderawi karena faktor usia rentanya. Bahkan hingga mengalami lupa ingatan dimana berbagai pengetahuan yang pernah diketahuinya mulai tidak diketahui lagi atau tidak dapat diingatnya kembali, atau mengalami fase tua renta dan pikun hingga terlihat seperti orang yang tidak berakal, tidak lagi mengetahui apa-apa yang pernah diketahuinya dan lupa ingatan terhadap pengetahuan kognitifnya yang telah diketahuinya (1996: 333).

Fenomena kepikunan dan beberapa kelemahan atau penurunan fungsi fisik dan psikis lainnya sebagai efek penuaan yang dialami seseorang yang berusia dewasa-tua terutama yang berumur lebih dari 75 tahun, sebenarnya telah diisyaratkan oleh Allah dalam firman-Nya berikut:

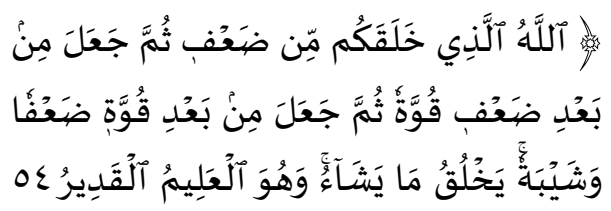

\begin{abstract}
"Allah-lah yang menciptakan kamu dari keadaan lemah, kemudian Dia menjadikan (kamu) sesudah keadaan lemah itu menjadi kuat, kemudian Dia menjadikan (kamu) sesudah kuat itu lemah (kembali) dan beruban. Dia menciptakan apa yang dikehendaki-Nya. Dan Dia Maha Mengetahui lagi Maha Kuasa." (Q.S. Al-Rum [30]: 54)
\end{abstract}

Menurut Muhammad Al-Amîn AlSyinqîthî (t.t.: VIII/488), maksud dan keadaan lemah yang pertama adalah kelemahan dalam proses awal penciptaan manusia (janin), sedangkan keadaan lemah yang kedua adalah kelemahan dalam masa tua saat menghadapi usia dewasa-tua seperti yang dikemukakan dalam beberapa ayat lainnya. Sedangkan dalam Tafsîr Al-Jalâlain (Al-Mahallî dan Al-Suyûthî, t.t.: 537) kelemahan yang pertama kali dinyatakan adalah kelemahan saat masa kanak-kanak (dha'f al-thufûlah) sedang kelemahan kedua adalah kelemahan karena masa tua (dha'falkibar) ketika mengalami sindrom penurunan ingatan dan lemahnya daya pikir kognitif atau demensia.

\section{Term Al-Syaib, Al-Syîb, dan Al- Syaibah}

Ketiga term yang dimaksud berasal dari akar kata yang sama, yaitu dari akar kata syâba-yasyîbu-syaiban-syaibatan-

masyîban; dimana al-syaib dan al-syaibah adalah mashdar, sedangkan al-syîb adalah bentuk plural dari al-asyyab yang merupakan isim fâ'il (Al-Fârabî, 2017: 737). Ketiga term tersebut berkaitan dengan makna memutihnya rambut (bayâdh alsya'r) atau rambut yang memutih karena beruban (al-sya'r al-abyadh) (Al-Na'âl, 2003: 440-441).

Dalam Al-Qur' an term al-syaib, al-syîb, dan al-syaibah masing-masing terdapat dalam satu ayat; al-syaib dalam Q.S. Maryam [19]: 4, al-syîb dalam Q.S. Al- 
Muzammil [73]: 17, dan al-syaibah dalam Q.S. Al-Rûm [30]: 54.

Allah berfirman:

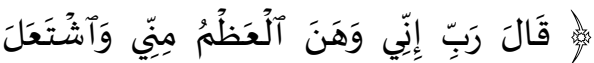

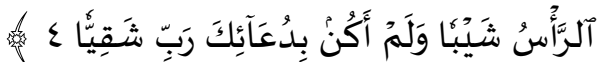

"Dia (Zakaria) berkata, "Wahai Tuhanku, sungguh tulangku telah lemah dan kepalaku telah dipenuhi uban, dan aku belum pernah kecewa dalam berdoa kepada-Mu, wahai Tuhanku." (Q.S. Maryam [19]: 4)

"Allah-lah yang menciptakan kamu dari keadaan lemah, kemudian Dia menjadikan (kamu) sesudah keadaan lemah itu menjadi kuat, kemudian Dia menjadikan (kamu) sesudah kuat itu lemah (kembali) dan beruban. Dia menciptakan apa yang dikehendaki-Nya. Dan Dia Maha Mengetahui lagi Maha Kuasa.” (Q.S. Al-Rum [30]: 54)

Selain $a l$-syîb yang merupakan kiasan, term al-syaib dan al-syaibah mudah dipahami seperti yang didefinisikan dalam beberapa kamus di atas. Sebagai tambahan pengetahuan terhadap aksentuasi makna keduanya, Al-Khathîb Al-Syarbînî (2018: III/356) menjelaskan, "kepalaku telah dipenuhi uban" maksudnya uban telah menyebar di rambut kepalanya seperti menyebarnya pijaran api dari kayu bakar (intasyara al-syaib fî sya'rihi kamâ yantasyiru syi'â'a al-nâr fî al-hathab); sedangkan makna al-syaibah adalah uban usia tua berupa rambut putih di kepala, umumnya terjadi pada usia 43 tahun yang merupakan umur dewasa akhir (late adults) kemudian menyebabkan penurunan dalam aktifitas fisik dan psikis setelah berumur 5063 tahun yang merupakan fase umur lanjut usia (olderly) (syaib al-haram wa hiya bayâdh al-sya'ri yahshulu awwaluhu fî alghâlib fî al-sanah al-tsâlitsah wa al-arba'în wa huwa awwal sinn al-iktihâl, wa al-akhdz fì al-naqsh bi al-fi'l ba'da al-khamsîn ilâ an yazîda al-naqsh fì al-tsâlitsah wa al-sittîn wa huwa awwal sinn al-syaikhûkhah) (AlSyarbînî, 2018: IV/376).

Dari Q.S. Maryam [19]: 4 dan Al-Rûm [30]: 54 di atas, hal yang harus diperhatikan oleh orang yang telah memasuki usia dewasa-tua (al-syaib, al-syîb, dan alsyaibah) adalah a) mengingat kelemahan dirinya karena faktor usia terutama ditimpa demensia yang banyak dialami, b) tidak putus asa atau lelah dalam berdoa, dan c) mempersiapkan diri sebelum kiamat datang, dimana kiamat terdekat adalah waktu kematiannya sendiri.

\section{Term Al-Syaikh dan Al-Syuyûkh}

Al-Syaikh bentuk pluralnya adalah alsyuyukkh, atau al-syiyukh secara general dapat diungkapkan bagi seseorang yang berusia 50 tahun hingga batas usia kematiannya (man balagha sinn al-khamsîn ilâ akhir 'umurihi). Sedangkan bila diungkapkan dengan term al-syaikhûkhah, maka dewasa-tua yang dimaksud secara general adalah orang berusia 50 hingga 80 tahun (al-sinn min khamsîn sanah ilâ tsamânîn sanah 'alâ al-ghâlib) (Al-Na'âl: 442).

Pendapat yang hampir identik juga dikemukakan oleh Muhammad AlFairûzâbâdî (2005: 254), bahwa dewasa-tua dengan term al-syaikh dan al-syuyûkh maksudnya adalah orang yang telah berusia renta (man istâbanat fihi al-sinn), yaitu yang berumur 50 atau 51 tahun hingga umur 80 atau sampai akhir usianya dalam kehidupan karena meninggal dunia. Menurutnya, bentuk plural dari al-syaikh selain alsyuyûkh adalah syiyûkh, asyyâkh, syiyakhah, syîkhah, syîkhân, masyyakhah, masyîkhah, masyyûkhâ', masyyukhâ', dan masyâyîkh.

Term al-syaikh dan al-syuyûkh terdapat dalam empat ayat, yaitu dalam Q.S. Hûd [11]: 72, Yûsuf [12]: 78, Al-Qashash [28]: 23, dan Al-Mu'min [40]: 67. Perhatikan dan renungkan firman Allah berikut: 


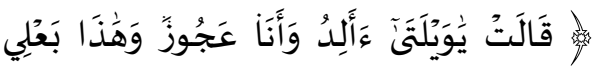

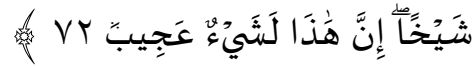

"Isterinya berkata, "Sungguh mengherankan, apakah aku akan melahirkan anak padahal aku adalah seorang perempuan tua, dan ini suamiku pun dalam keadaan yang sudah tua pula? Sungguh, ini benar-benar suatu yang sangat aneh." (Q.S. Hûd [11]: 72)

“...kemudian (kamu dibiarkan hidup) supaya kamu sampai kepada masa (dewasa), kemudian (dibiarkan kamu hidup lagi) sampai tua, di antara kamu ada yang diwafatkan sebelum itu. (Kami perbuat demikian) supaya kamu sampai kepada ajal yang ditentukan dan supaya kamu memahami(nya).” (Q.S. AlMu'min [40]: 67)

Term syaikhan dalam Q.S. Hûd [11]: 72 merujuk kepada Ibrahim yang telah berusia tua. Dalam hal ini Ibn Al-Jauzî (2002: 663) mengemukakan empat pendapat mengenai kisaran umur Ibrahim yang dinyatakan sebagai orang yang berusia tua. Kesimpulannya usia tua Ibrahim berkisar antara umur 70-120 tahun, yang menunjukkan usia sangat tua.

\section{Term Al-'Ajûz}

Menurut Al-Fârabî (2017: 867) dan AlRâzî (t.t.: 230-521), term al-'ajûz yang diidentikkan dengan term dewasa-tua dalam penelitian ini digunakan untuk laki-laki dan perempuan, berasal dari akar kata al-'ajz yang berarti kelemahan (al-dha'f). Namun umumnya digunakan untuk perempuan, maka didefinisikan sebagai perempuan yang berusia tua (al-mar'ah al-kabîrah), atau perempuan tua renta (al-haram) yang mengalami kelemahan (al-'ajz) dan pikun (al-khurq) (Majma' Al-Lughah Al'Arabiyyah, 2012: 440), walaupun boleh saja dipergunakan untuk laki-laki tua.
Dari keempat ayat yang mengungkapkan term al-'ajûz, semuanya menjelaskan tentang perempuan berusia lanjut atau perempuan yang sudah tua renta. Dalam Q.S. Hûd [11]: 72 dan Al-Dzâriyât [51]: 29 term al-'ajûz merujuk kepada Sârah istri Nabi Ibrâhîm, sedangkan dalam Q.S. Al-Syu'arâ' [26]: 171 dan Al-Shâffât [37]: 135 merujuk kepada istri Nabi Lûth (Nukhbah min Al-'Ulamâ', 2011: 254).

Dalam Disertasi Doktoral Muhammad ibn Nâshir Al-Humayyid (2001: 143-144 dan 155-165) yang kemudian diterbitkan menjadi buku populer, istri Nabi Lûth memiliki beberapa nama yang masih diperselisihkan validitas faktualnya, karena selain durhaka kepada suaminya juga karena tidak ada faidah dalam pengetahuan terhadap namanya. Sedang istri Nabi Ibrâhîm memiliki nama lengkap Sârah bint Hârûn bin Nâhûr bin Sârûkh bin Râ'û bin Fâligh.

Bedanya, Sârah istri Nabi Ibrâhîm adalah perempuan beriman yang salehah dan taat kepada suami, sedangkan istri Nabi Lûth merupakan perempuan kafir lagi durhaka kepada suaminya.

Ayat tentang perempuan salehah yang berusia dewasa-tua ('ajûz) hingga dianugerahkan kebahagiaan di masa tuanya adalah firman Allah berikut:

"Dia (isterinya berkata), "Sungguh ajaib, mungkinkah aku akan melahirkan anak padahal aku adalah seorang perempuan tua, dan suamiku ini sudah sangat tua? Ini benar-benar sesuatu yang ajaib." (Q.S. Hûd [11]: 72)

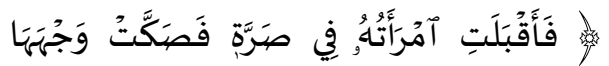

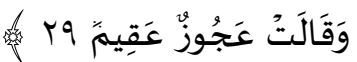


perempuan tua yang mandul."

(Q.S. Al-Dzâriyât [51]: 29)

Sedangkan ayat tentang perempuan dewasa-tua ('ajûz) yang kafir lagi durhaka kepada suaminya adalah firman Allah dengan susunan ayat yang identik terdapat dalam Q.S. Al-Syu'arâ' [26]: 171 dan AlShâffât [37]: 135 yang dikisahkan mendapatkan siksa dari Allah.

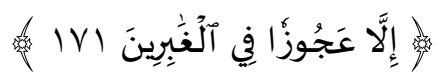

"Kecuali seorang perempuan tua (isterinya), yang termasuk dalam golongan yang tinggal."

Ibn Al-Jauzî (2002: 663) sebagaimana interpretasinya terhadap term syaikhan dalam Q.S. Hûd [11]: 72 yang merujuk kepada Ibrahim, ia mengemukakan pula beberapa pendapat mengenai kisaran umur Sârah yang dinyatakan sebagai perempuan yang juga telah berusia tua, bahwa usia tuanya berkisar antara umur 70-98 tahun. Sedangkan Al-Khathîb Al-Syarbînî (2018: II/474) berpendapat bahwa usia Sârah berkisar antara 90 atau 99 tahun.

\section{Term Al-Kabîr dan Al-Kibar}

Berdasarkan penelusuran, ayat terbanyak yang mendeskripsikan usia dewasa-tua adalah ayat-ayat yang menggunakan term al-kabîr (dan al-kibar) sebagaimana yang terdapat dalam tabel. Tepatnya terdapat dalam delapan ayat yang setelah dipilih dan dipilah sangat berkaitan dengan term dewasa-tua, yaitu Q.S. AlBaqarah [2]: 266, Âli 'Imrân [3]: 40, Ibrâhîm [14]: 39, Al-Hijr [15]: 54, Al-Isrâ' [17]: 23, Maryam [19]: 8, Al-Qashash [28]: 23, dan Yûsuf [12]: 78.

Dalam kitab Al-Mufradât fi Gharîb AlQur'ân (Al-Ashfahânî, t.t.: 421), al-kabîr memiliki arti lanjut usia atau berumur tua (musinn); sedang dalam kitab Mausû'ah AlAlfâzh Al-Qur'âniyyah (Al-Na'âl, 2003: 638), al-kabîr adalah orang tua dan lansia atau bahkan telah memasuki usia renta (altaqaddum wa al-tha'n fi al-sinn).
Contohnya adalah firman Allah berikut:

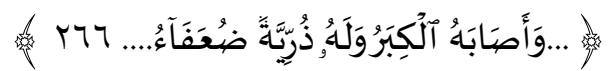

“...kemudian datanglah masa tuanya sedang dia memiliki keturunan yang masih kecilkecil..." (Q.S. Al-Baqarah [2]: 266)

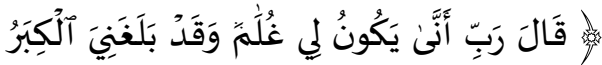

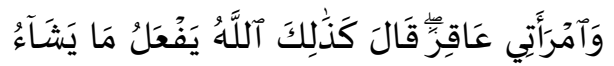

$$
\text { 禹 } \varepsilon \text {. }
$$

"Dia (Zakaria) berkata, "Wahai Tuhanku, bagaimana aku bisa mendapat anak, sedang aku sudah sangat tua dan isteriku pun mandul?". Dia (Allah) berfirman, "Demikianlah, Allah berbuat apa yang Dia kehendaki." (Q.S. Âli 'Imrân [3]: 40)

Yang dimaksud al-kabîr dan al-kibar, atau kibar al-sinn dalam kedua ayat tersebut menurut Muhammad 'Alî Al-Syaukânî (2007: 185) adalah usia seseorang dimana ketika ia telah memasukinya diperkirakan dirinya akan mulai mengalami kelemahan dalam beraktifitas (mizhannah syiddah alhâjah li mâ yalhaqu shâhibuhu min al-'ajz 'an ta' âthî al-asbâb), yaitu usia menjelang ajal yang telah menampakkan tandatandanya (li kaunihi thalî'ah min thalâ ' $i$ ' almaut) (Al-Syaukânî, 2007: 216).

\section{Term Nu'ammir dan Yu'ammar (serta Mu'ammar)}

Usia dewasa-tua yang dapat ditelusuri dari term nu'ammir (nu'ammirkum dan nu'ammirhu) dan yu'ammar (serta mu'ammar) berasal dari maknanya yang jelas, yaitu berarti usia atau umur yang dipanjangkan seperti yang terdapat dalam Q.S. Fâthir [35]: 37, Yâsîn [36]: 68, AlBaqarah [2]: 96, dan Fâthir [35]: 11. 
Allah berfirman:

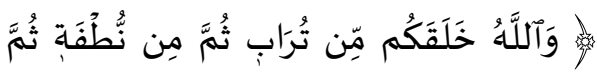

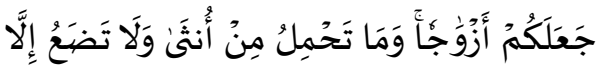

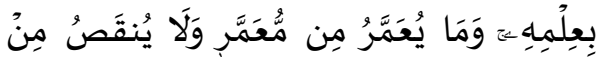

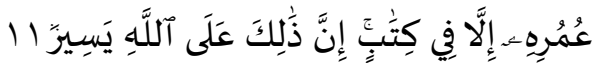

"Dan Allah menciptakan kamu dari tanah kemudian dari air mani, kemudian Dia menjadikan kamu berpasangan (laki-laki dan perempuan). Tidak ada seorang perempuan pun mengandung dan melahirkan melainkan dengan sepengetahuan-Nya. Dan tidak dipanjangkan umur seseorang, dan tidak pula dikurangi umurnya, melainkan (sudah ditetapkan) dalam Kitab (Lauh Mahfuzh). Sungguh, yang demikian itu mudah bagi Allah.” (Q.S. Fâthir [35]: 11)

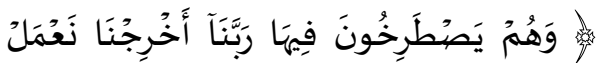

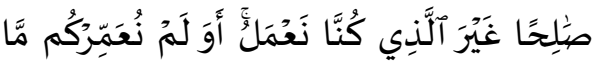

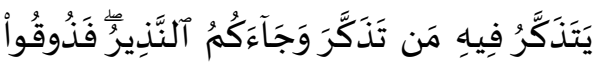

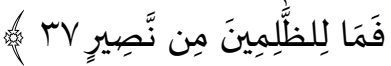

"Dan mereka berteriak di dalam neraka itu, "Wahai Tuhan kami, keluarkanlah kami (dari neraka), niscaya kami akan mengerjakan kebajikan, yang berlainan dengan yang telah kami kerjakan dahulu.". (Dikatakan kepada mereka), Bukankah Kami tidak memanjangkan umurmu untuk dapat berpikir bagi orang yang mau berpikir, padahal telah datang kepadamu seorang pemberi peringatan?. Maka rasakanlah (azab Kami), dan bagi orang-orang yang zalim tidak ada seorang penolong pun." (Q.S. Fâthir [35]: 37)
Ibn Katsîr (1999: VI/539) menjelaskan bahwa maksud dari "orang yang dikurangi umurnya (yunqashu min 'umurihi)" dalam Q.S. Fâthir [35]: 11 adalah orang yang meninggal dunia sebelum berusia 60 tahun (alladzî yamûtu qabla sittîn sanah), sehingga orang yang dipanjangkan umurnya (yu'ammaru min mu'ammar) adalah orang yang memiliki umur lebih dari 60 tahun. Ketika menafsirkan Q.S. Fâthir [35]: 37, Ibn Katsîr (VI/554-556) juga mengemukakan cukup banyak pendapat tentang makna "Kami tidak memanjangkan umurmu", sebagai usia 17, 18, 20, 40, 60, atau 70 tahun, atau hingga usia 120 tahun menurut sebagian pakar bidang kesehatan. Jika pendapat ini direlasikan dengan makna term dewasa-tua yang dimaksud dalam artikel, berarti yang dimaksud adalah usia 40-120 tahun atau bahkan usia lebih dari 120 tahun hingga kematiannya.

Adapun maksud dan tafsir dari al-nadzîr dalam Q.S. Fâthir [35]: 37, menurut AlThabarî (2001: XIX: 387) adalah Nabi Muhammad, atau uban yang mulai tumbuh.

Dalam ayat lain Allah berfirman:

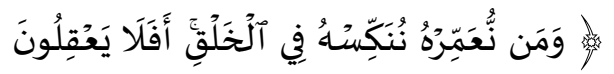<smiles>[Te]</smiles>

"Dan barangsiapa yang Kami panjangkan umurnya niscaya Kami kembalikan dia kepada kejadian(nya). Maka apakah mereka tidak memikirkan." (Q.S. Yâsîn [36]: 68)

Maksud dari "Kami panjangkan umurnya (nu'ammirhu)" dalam ayat ini menurut Muhammad Al-'Utsaimîn (1424 H.: 239-240), bahwa ketika seseorang berumur panjang, maka dia akan kembali mengalami kelemahan seperti sebelumnya (nunakkishu fi al-khalq), yaitu masa kanakkanak. Kelemahan tersebut bersifat multikompleks, meliputi kelemahan atau penurunan dalam kekuatan fisik, rasionalitas, dan intelektualitas pemikiran 
(al-warâ' fi al-quwwah al-badaniyyah wa al-'aqliyyah wa al-fikriyyah) serta kembali mengalami fase ardzal al-'umur, seperti yang dijelaskan dalam Q.S. Al-Nahl [16]: 70 dan Al- Hajj [22]: 5.

Sedangkan tafsir dari "Kami kembalikan dia kepada kejadian(nya)" adalah dikembalikan seperti keadaannya saat masih kanak-kanak, yaitu mengalami demensia dan kelemahan hingga tidak lagi dapat mengetahui pengetahuan yang telah diketahui sebelumnya, menurut Al-Thabarî (2001: XIX/478).

\section{Term Thâla/Tathâwala Al-’Umur}

Term thâla/tathâwala al-'umur (dewasa-tua) yang dipisahkan oleh huruf jarr 'alâ kemudian menjadi sebuah frase idiomatik hanya terdapat dalam dua ayat saja, yaitu dalam Q.S. Al-Anbiyâ' [21]: 44 (thâla 'alaihim al-'umur) dan Al-Qashash [28]: 45 (tathâwala 'alaihim al-'umur).

Dalam hal ini Allah berfirman:

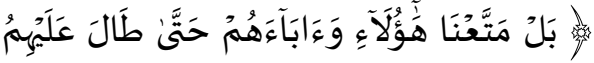

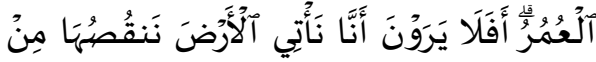

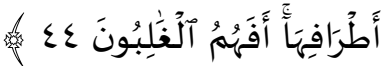

"Sebenarnya Kami telah memberi mereka dan nenek moyang mereka kenikmatan (hidup di dunia) hingga panjang usia mereka. Maka apakah mereka tidak melihat bahwa Kami mendatangi negeri (yang berada di bawah kekuasaan orang kafir), lalu Kami kurangi luasnya dari ujungujung negeri. Apakah mereka yang menang?" (Q.S. Al-Anbiyâ' [21]: 44)

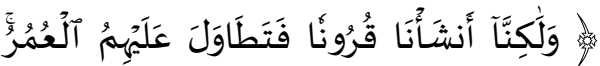

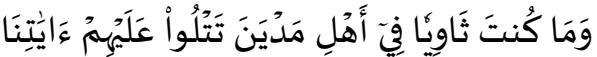

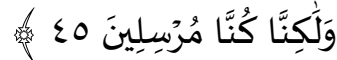

"Tetapi Kami telah mengadakan beberapa umat, dan telah berlalu atas mereka masa yang panjang, dan engkau (Muhammad) tidak tinggal bersama-sama penduduk Madyan dengan membacakan ayatayat Kami kepada mereka, tetapi Kami telah mengutus rasul-rasul."

\section{(Q.S. Al-Qashash [28]: 45)}

Term thâla al-'umur atau tathâwala al'umur dalam kedua ayat tersebut memang tidak berkaitan langsung dengan usia dewasa-tua dan batasan umurnya, karena secara implisit berkaitan dengan penangguhan waktu yang sering kali memperdaya dan menipu seseorang dalam kehidupannya (Al-Baghawî, 2002: V/320), yaitu dalam menepati janji Allah yang seharusnya tidak boleh dilupakan. Namun janji tersebut kemudian terlupakan dan akhirnya tidak dapat ditepati (Al-Baghawî, 2002: VI/210). Walaupun demikian, secara eksplisit dapat dikaitkan dengan penangguhan umur hingga usia dewasa-tua yang juga sering memperdaya seseorang dalam perjalanan kehidupannya yang berumur panjang. Efek panjang umur seperti ini sepantasnya disadari, disikapi, dan disiasati baik-baik oleh orang yang lanjut usia.

Wahbah Al-Zuhailî (1996: 326) menegaskan bahwa ketertipuan orang-orang musyrik Arab seperti yang diungkap dalam Q.S. Al-Anbiyâ' [21]: 44 adalah bersamaan dengan limpahan nikmat yang dianugerahkan Allah kepada mereka, sekalipun mereka berumur panjang dalam hidupnya.

Selain dalam ayat-ayat Al-Qur'an tersebut, term dewasa-tua juga diungkapkan dalam beberapa teks hadis yang berasal dari sabda Nabi Muhammad berikut:

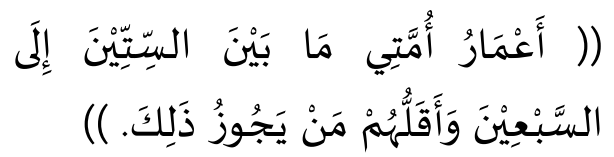

"Rentang umur umatku antara 60 hingga 70 tahun, dan sedikit dari mereka yang melebihi umur 
tersebut." (H.R. Al-Tirmidzî, Ibnu Mâjah, dan Al-Hâkim)

$$
\begin{aligned}
& \text { (أَعْذَرَ اللَّهُ إِلَى امْرِيُ أَخََّرَ أَجَلَلَهُ حَتَّى }
\end{aligned}
$$

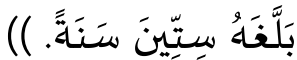

"Allah tidak akan menerima argumen kepada orang yang diakhirkan ajalnya, hingga sampai pada usia 60 tahun." (H.R. AlBukhârî)

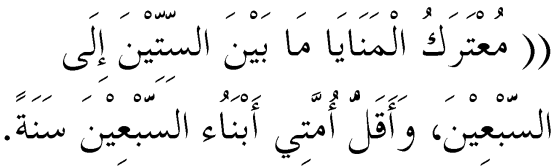

$(($

"Pergulatan kematian berada pada kisaran usia 60-70 tahun. Sedikit dari umatku yang berusia hingga 70 tahun." (H.R. Al-Hakim dan AlNasâ'î)

\section{Implikasi Edukatif Makna Term Dewasa- Tua dalam Al-Qur'an}

Term dewasa-tua dengan berbagai istilahnya yang terdapat dalam dan dipergunakan oleh Al-Qur'an memiliki tipologi dan karakteristik substansialnya sebagaimana yang terdapat dalam berbagai interpretasi para mufassir, baik kalangan klasik maupun pakar kontemorer, juga memiliki implikasi langsung berkaitan dengan dengan aspek pendidikan Islam, antara lain:

1. Menyadari hakekat substansial usia dewasa-tua dengan sebenar-benarnya.

Kesadaran ini terutama harus dimiliki oleh seseorang yang usianya telah menginjak umur 40 tahun. Hal ini pulalah mungkin yang menyebabkan lahirnya adagium populer yang menyatakan bahwa "hidup dimulai pada usia 40 tahun (life begin at fortt)". Bagi seorang muslim, ini telah diingatkan Allah dalam firman-Nya dalam Q.S. Al-Ahqâf [46]: 15.
Ketika seseorang memasuki usia dewasa-tua yang dimulai dari umur 40 tahun terlebih ketika usianya semakin beranjak menuju umur 60-70 tahun atau bahkan lebih, ia harus menyadari karakteristik usia dewasa-tua dengan segala kelebihan dan kekurangannya, minimal seperti yang terdapat dalam ayat-ayat yang dikaji dalam artikel ini dan interpretasi dari para mufassir.

Kelebihan yang ada pada usia dewasatua beserta umur yang telah dilaluinya harus disyukuri, karena banyak yang meninggal dunia sebelum menginjak usia dewasa-tua. Sedangkan kelemahan fisik dan psikis terutama kepikunan yang banyak dialami, itu harus disabari. Dua hal ini, syukur dan sabar merupakan kewajiban agama yang telah diperintahkan dalam sabda Rasulullah berikut:

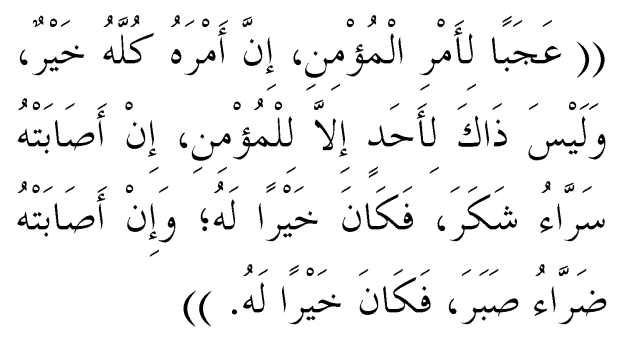

"Sungguh menakjubkan urusan seorang mukmin. Seluruh urusannya merupakan kebaikan, dan ini tidak dimiliki kecuali oleh seorang mukmin. Jika mendapatkan kenikmatan, ia bersyukur dan itu baik baginya. Sedangkan jika tertimpa musibah, ia bersabar dan itu juga baik baginya." (H.R. Muslim)

Di samping itu, bersyukur (idzâ un 'ima 'alaihi syakara) dan bersabar (idzâ ubtuliya shabara) serta beristighfar ketika berbuat dosa dan kesalahan (wa idzâ adznaba istaghfara), ketiganya merupakan kunci bahagia ('unwân sa'âdah al-'abd) sebagaimana yang dikemukakan oleh Ibn Qayyim Al-Jauziyyah (1987: 11).

Oleh karena itu, agar kesadaran tentang hakekat substansial dari usia dewasa-tua ini 
dapat dipahami, selain mengkaji ayat-ayat tentang dewasa-tua beserta interpretasinya, sebaikanya membaca buku-buku tentangnya, antara lain buku Rahasia Usia 40 Tahun (Wa Balagha Arba'în Sanah: Risâlah Taujîhiyyah li Man Balagha Arba'în Sanah) karya Anas Ahmad Karzûn, Ketika Usia 40 Tiba (Jaddid Hayâtaka: Risâlah ilâ Man Jâwaza Al-Arba'în) karya Muhammad Mûsâ Al-Syarîf, Misteri Umur 40 Tahun (Yâ Ibn Al-Arba'în) dan Misteri Umur 60 Tahun: Menyibak Pernik-pernik Usia Kritis di Ambang Kematian (Yâ Shâhib Al-Sittîn) karya 'Alî ibn Sa'îd ibn Da'jam, serta buku Bagaimana Panjang Umur Penuh Berkah? (Kaifa Tuthîlu 'Umraka?) karya Muhammad bin Ibrahim Al-Nu'aim (2006) dan kitab Mu'tarak Al-Manâyâ Mâ baina Sittîn ilâ Sab'în Sanah: Wa Dzikr Al-A'mâl min Al'Isyrîn ilâ Al-Tis'în karya 'Abd Al-Rahmân Yûsuf Al-Farhân (2015).

2. Memfokuskan orientasi kehidupan untuk beramal saleh dan kehidupan ukhrawi.

Implikasi ini antara lain dapat direnungkan dalam Q.S. Al-Ahqâf [46]: 15 dan Fâthir [35]: 37 serta ayat-ayat lainnya yang memerintahkan untuk beramal saleh dan agar lebih mengutamakan kehidupan akhirat dan sabda Rasulullah berikut:

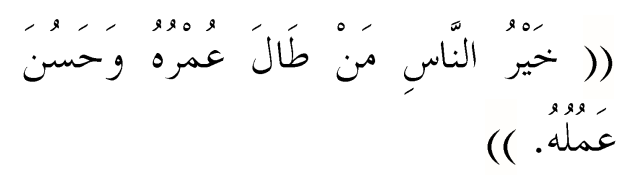

"Sebaik-baik orang adalah yang panjang umur dan baik amalannya." (H.R. Ahmad dan

\section{Al-Tirmidzî)}

Oleh karena itu, berdasarkan Q.S. Fâthir [35]: 37 dan Al-Nashr [110]: 1 serta haditshadits yang dikemukakannya, Al-Nawawî (2007: 57-59) dalam kitab Riyâdh AlShâlihîn membuat pembahasan yang diberi judul anjuran menambah amal kebajikan di akhir usia/dewasa tua (al-hatsts 'alâ alizdiyâd min al-khair fî awâkhir al-'umur).
Amal saleh dan amal kebajikan tersebut harus istikamah dilakukan oleh orang dewasa-tua hingga akhir kehidupannya dengan meraih akhir yang baik atau husn alkhatimah dan mewaspadai serta menghindari akhir kehidupan yang buruk atau $s \hat{u}$ ' al-khâtimah. Rasulullah bersabda:

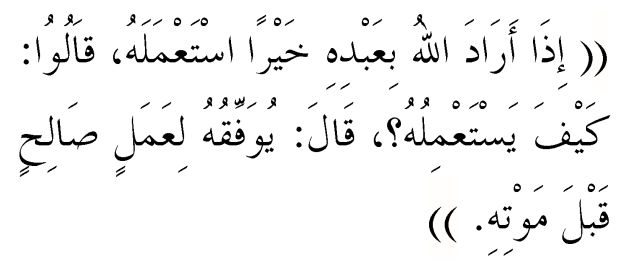

"Jika Allah menghendaki kebaikan pada hambanya, maka Dia akan memanfaatkannya". Para sahabat bertanya, "Bagaimana Allah akan membimbingnya dalam amal kebajikan?". Maka Rasulullah menjawab, "Allah akan memberinya taufik untuk beramal shalih sebelum (atau hingga) ia meninggal." (H.R. Aḥmad, AlTirmidzî, dan Al-H彑âkim)

3. Mengintegrasikan pendekatan belajar andragogi-heutagogi.

Orang yang dikategorikan berusia dewasa-tua adalah orang-orang tetap harus belajar bahkan harus merasakan pendidikan seumur hidup (life long education), baik di lingkungan pendidikan formal, nonformal, maupun informal sekalipun. Model dan pendekatan pendidikan yang dirasakan cocok sesuai dengan hakekat substansial dan karakteristik usia dewasa tua adalah pendidikan orang dewasa (andragogy) dan dipadu atau diintegrasikan dengan pendidikan kesadaran atau kemandirian (heutagogy).

Andragogi dipahami sebagai cara belajar atau pembelajaran orang dewasa yang dapat menentukan sendiri prosesnya (apa dan bagaimana belajar, student learned) (Danim, 2015: 144-145). Sedangkan heutagogi merupakan studi tentang belajar yang ditentukan oleh diri pembelajar sendiri. Heutagogi berpusat pada perbaikan belajar 
cara belajar, dua keluk belajar, kesempatan belajar universal, proses non-linier, dan arah sejati diri pelajar. Heutagogi mensyaratkan inisiatif pendidikan termasuk peningkatan keterampilan (Mariah H., 2015: 22-23).

Kedua model pembelajaran andragogiheutagogi tersebut diintegrasikan agar pembelajaran bagi usia dewasa-tua semakin lebih bermakna; dimana pembelajaran seumur hidup dilakukan secara sendiri dan penuh kesadaran dalam kemandiriannya, atau pembelajaran yang dilakukan dari, oleh, dan untuk sendiri.

4. Menjaga kesehatan fisik dan psikis (mental) serta produktifitas

Hal ini dilakukan terutama agar tiga implikasi sebelumnya dapat tetap terwujud atau mampu diberdayakan secara optimal dan maksimal.

\section{E. KESIMPULAN}

Berdasarkan pemaparan dan analisisnya, terutama dari uraian hasil dan pembahasan dalam artikel ini, term dewasatua dalam Al-Qur'an dapat diidentifikasi dari delapan term utama dan beberapa bentuk derivasinya berdasarkan penelusuran terhadap kitab Al-Mu'jam Al-Mufahras li Alfâzh Al-Qur'ân Al-Karîm karya Muhammad Fu'âd 'Abd Al-Bâqî, kitab $A l$ Dalîl Al-Mufahras li Alfâzh Al-Qur'ân AlKarîm bi Hâsyiyah Al-Mushhaf Al-Syarîf karya Husain Muhammad Fahmî Al-Syâfi' dan kitab Al-Mu'jam Al-Maudhû'î li Ayât Al-Qur'ân Al-Karîm karya Hanân 'Abd AlMannân. Term dewasa-tua yang dimaksud adalah term arba'în sanah, ardzal al-'umur, al-syaib (al-syîb dan al-syaibah), al-syaikh (dan al-syuyûkh), al-'ajûz, al-kabîr (dan alkibar), kata kerja (fi'il) nu'ammir dan yu'ammar (serta isim mu'ammar), serta frase idiomatik thâla/tathâwala al-'umur.

Term-term dewasa-tua tersebut terdapat dalam 28 ayat dengan beberapa ayat di antaranya muncul secara berulang serta memiliki aksentuasi makna yang mendalam berdasarkan penafsiran atau interpretasi para mufassir. Di antara mufassir klasik dan kontemporer yang dieksplorasi interpretasi penafsiran dan corak pemikirannya adalah Al-Sa'dî, Al-Zamakhsyarî, Al-Farrâ', AlQâdhî Al-Baidhâwî, Ibn 'Athiyyah AlAndalusî, Ibn Katsîr, Al-Qurthubî, Ibn AlJauzî, Wahbah Al-Zuhailî, Muhammad AlAmîn Al-Syinqîthî, Jalâl Al-Dîn Al-Mahallî dan Jalâl Al-Dîn Al-Suyûthî, Al-Khathîb AlSyarbînî, Al-Syaukânî, Al-Thabarî, Al'Utsaimîn, dan Al-Baghawî, serta ditunjang oleh berbagai referensi otoritatif lainnya yang terkait.

Di samping itu, berbagai term dewasatua yang disebutkan dalam dan dipergunakan oleh Al-Qur'an memiliki implikasi yang saling berkaitan antara satu dengan yang lainnya, terutama terkait dengan hal-hal penting yang berhubungan dengan aspek wawasan keislaman dan pendidikan Islam seperti yang telah dipaparkan dalam artikel jurnal ini.

\section{DAFTAR PUSTAKA}

\section{Referensi dari Jurnal}

Amin, K. (2017). Tipologi Pemuda dalam Al-Qur'an: Analisis HistorisPsikologis. Skripsi. Yogyakarta: Jurusan Tafsir Hadits Khusus Fakultas Ushuluddin, Filsafat dan Politik Universitas Islam Negeri Sunan Kalijaga.

Anshori, M. (2016). Pemuda dalam AlQur'an dan Hadis. Jurnal Kajian Islam Interdisipliner, 1(2).

Mariah H., S. (2015). Membangun Revolusi Berpikir Mahasiswa PLS Melalui Pendekatan Heutagogi. Jurnal Handayani, 4(1).

Mustaqim, A. (2019). Berbagai Penyebutan Term Anak dalam Al-Qur'an: Implikasi Maknanya dalam Konteks Qur'anic Parenting. Jurnal Lektur Keagamaan, 17(2). 
Mutaqin, J. Zainal. (2017). Lansia dalam AlQur'an Kajian Term (Tafsir AsySyaikh, Al-Kibar, Al-Ajuz, Ardzal AlUmur). Skripsi. Semarang: Jurusan Tafsir Hadis Fakultas Ushuluddin dan Humaniora Universitas Islam Negeri Walisongo.

Nuryadin. (2014). Kedewasaan dalam Perspektif Al-Qur'an: Kajian Tafsir Tematik. Skripsi. Makassar: Prodi Ilmu Al-Qur'an dan Tafsir Fakultas Ushuluddin dan Pemikiran Islam Universitas Islam Negeri Alauddin.

Wani, M. (2019). Pemuda dalam Al-Qur'an dan As-Sunnah: Pemuda Islam yang Berkualitas Tidak Lepas dari Pendidikan Orang Tua yang Totalitas. Al-Dzikra: Jurnal Studi Ilmu Al-Qur'an dan Al-Hadits, 13(1).

\section{Refefensi dari Buku}

'Abd Al-Bâqî, M. Fu'âd. (1988). Al-Mu'jam Al-Mufahras li Alfâzh Al-Qur'ân AlKarîm. Beirut: Dâr Al-Jîl dan Dâr AlHadîts Mesir.

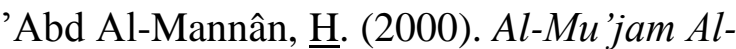
Maudhû'î li Ayât Al-Qur'ân Al-Karîm. Oman: Bait Al-Afkâr Al-Dauliyyah.

Ahmad, Y. Al-Hajj. (2016). Mukjizat AlQur'an yang Tak Terbantahkan. Solo: PT Aqwam Media Profetika.

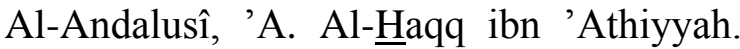
(2007). Al-Muharrar Al-Wajîz fì Tafsîr Al-Kitâb Al-'Azîz. ed. Al-Rahâlah AlFârûq, et.al. Qathar: Wizârah Al-Auqâf wa Al-Syu'ûn Al-Islâmiyyah dan Dâr Al-Khair Damaskus.

Al-Ashfahânî, H. ibn Muhammad AlRâghib. (t.t.) Al-Mufradât fî Gharîb AlQur'ân. ed. Muhammad Sayyid Kailânî. Beirut: Dâr Al-Ma'rifah.

Al-Baghawî, $\underline{\text { H. }}$ ibn Mas'ûd. (2002). Ma'âlim Al-Tanzîl. ed. Muhammad 'Abd Allah Al-Namr, 'Utsmân bin Jum'ah Dhumairiyyah, dan Sulaimân Musallam Al-ㅁarasy. Riyadh: Dâr Thayyibah.
Al-Baidhâwî, 'A. Allah ibn 'Umar ibn Muhammad Al-Qâdhî. (2018). Anwâr Al-Tanzîl wa Asrâr Al-Ta'wîl. ed. Dhiyâ' Al-Dîn ibn Ibrâhîm 'Abd AlLathîf. Kairo: Syirkah Al-Quds.

Al-Bârûdî, 'I. Zakî. (t.t.) Al-I'jâz Al-'Ilmî fî Al-Qur'ân wa Al-Sunnah. Kairo: AlMaktabah Al-Taufiqiyyah.

Al-Dimasyqî, I. ibn 'Umar ibn Katsîr AlQurasyî. (1999). Tafsîr Al-Qur'ân Al'Azhîm. ed. Sâmî ibn Muhammad AlSalâmah. Riyadh: Dâr Thayyibah.

Al-Dimasyqî, Y. ibn Syaraf Al-Nawawî. (2007). Riyâdh Al-Shâlihîn min Kalâm Sayyid Al-Mursalîn. ed. Mâhir Yâsîn Al-Fahl. Damaskus Beirut: Dâr Ibn Katsîr.

Al-Fairûzâbâdî, M. ibn Ya'qûb. (2005). AlQâmûs Al-Muhîth. Beirut: Mu'assasah Al-Risâlah.

Al-Fârabî, I. ibn Nashr ibn Hammâd Al-

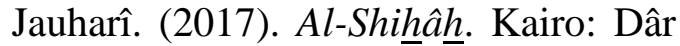
Al-Âfâq Al-'Arabiyyah.

Al Farabi, M. (2018). Pendidikan Orang Dewasa dalam Al-Qur'an. Jakarta: Kencana Prenadamedia Group.

Al-Farhân, 'A. Al-Rahmân Yûsuf. (2015). Mu'tarak Al-Manâyâ Mâ baina Sittîn ilâ Sab'în Sanah: Wa Dzikr Al-A'mâl min Al-'Isyrîn ilâ Al-Tis'în. Beirut: Dâr Al-Basyâ'ir Al-Islâmiyyah dan Maktabah Nizhâm Ya'qûbî AlKhâshshah Bahrain.

Al-Farrâ', Y. ibn Ziyâd. (2017). Ma'ânî AlQur'ân. ed. Dhiyâ' Al-Dîn ibn Ibrâhîm 'Abd Al-Lathîf. Kairo: Syirkah AlQuds.

Al-Ghulâyainî, M. (1994). Jâmi' Al-Durûs Al-'Arabiyyah. ed. 'Abd Al-Mun'im Khafâjah. Beirut: Al-Maktabah Al'Ashriyyah.

Al-Humayyid, M. ibn Nâshir. (2001). Qishahsh Al-Nisâ' fî Al-Qur'ân AlKarîm: WaAl-Durûs wa Al-'Ibar wa AlAhkâm Al-Mustafâdah minhâ. Lahore Pakistan: Dâr Al-Kitâb wa Al-Sunnah. 
Al-Jauzî, 'A. Al-Rahmân ibn 'Ali ibn Muhammad. (2002). Zâd Al-Masîr fî 'Ilm Al-Tafsîr. Beirut: Al-Maktab AlIslâmî dan Dâr Ibn Hazm Beirut.

Al-Jauziyyah, M. ibn Abî Bakr ibn Qayyim. (1987). Al-Wâbil Al-Shayyib min AlKalim Al-Thayyib. ed. Muhammad 'Abd Al-Rahmân 'Awadh. Kairo: Dâr Al-Rayyân.

Al-Juhnî, $\underline{\mathrm{H}}$. 'Athiyyah Al-Thaurî. (2001). Al-Daur Al-Tarbawî li Al-Wâlidain: Fî Tansyi'ah Al-Fatâh Al-Muslimah fî Marhalah Al-Murâhaqah. Riyadh: Majallah Al-Bayân.

Al-Juhnî, $\underline{\mathrm{H}}$. 'Athiyyah Al-Thaurî. (2001). Al-Daur Al-Tarbawî li Al-Wâlidain: Fî Tansyi'ah Al-Fatâh Al-Muslimah fì Marhalah Al-Thufûlah. Riyadh: Majallah Al-Bayân.

Al-Jurjânî, 'A. Al-Qâhir ibn 'Abd AlRahmân ibn Muhammad. (1992). Kitâb Dalấil Al-I'jâzz. ed. Mahmûd Muhammad Syâkir. Mesir: Mathba'ah Al-Madanî dan Dâr Al-Madanî Jeddah.

Al-Khawârizmî, M. ibn 'Umar AlZamakhsyarî. (2017). Al-Kasysyâf 'an Haqâ 'iq Al-Tanzîl wa 'Uyûn Al-Ta 'wîl fî̀ Wujûh Al-Ta'wîl. ed. Ahmad Jâd. Kairo: Syirkah Al-Quds.

Al-Mahallî, J. Al-Dîn dan Al-Suyûthî, J. AlDîn. (t.t.) Tafsir Al-Jalâlain. Mesir: Dâr Al-Hadîts.

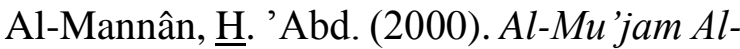
Maudhû̀î li Âyât Al-Qur'ân Al-Karîm. Yordania: Bait Al-Afkâr Al-Dauliyyah.

Al-Na'âl, M. Fauzî. (2003). Mausû'ah AlAlfâzh Al-Qur'âniyyah. Aleppo: Maktabah Dâr Al-Turâts dan Dâr AlYamâmah Damaskus.

Al-Nu'aim, M. bin Ibrahim. (2006). Bagaimana Panjang Umur Penuh Berkah?. Jakarta: PT Darul Falah.

Al-Râzî, M. ibn Abî Bakr ibn 'Abd AlQâdir. (t.t.). Mukhtâr Al-Shihâh $\underline{h}$.(Kairo: Syirkah Al-Quds.

Al-Sa'dî, 'A. Al-Rahmân ibn Nâshir. (2000). Taisîr Al-Karîm Al-Rahmân fî̀ Tafsîr
Kalâm Al-Mannân. ed. 'Abd AlRahmân ibn Mu'allâ Al-Luwaihiq. Beirut: Mu'assasah Al-Risâlah.

Al-Syâfi'î, H. Muhammad Fahmî. (2008). Al-Dalîl Al-Mufahras li Alfâzh AlQur'ân Al-Karîm bi Hâsyiyah AlMushhaf Al-Syarîf. Kairo: Dâr AlSalâm.

Al-Syarbînî, M. ibn Muhammad. (2018). AlSirâj Al-Munîr fî Al-I'ânah 'alâ Ma'rifah Ba'dh Ma'ânî Kalâm Rabbinâ

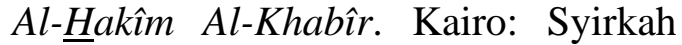
Al-Quds.

Al-Syarîf, M. Mûsâ. (2003). Jaddid Hayâtaka. Jeddah: Dâr Al-Andalus AlKhadhrâ'.

Asy-Syarif, M. Musa. (2017). Ketika Usia 40 Tiba. Solo: Mumtaza.

Al-Syaukânî, M. ibn 'Alî ibn Muhammad. (2007). Fath Al-Qadîr: Al-Jâmi' baina Fannai Al-Riwâyah wa Al-Dirâyah min 'Ilm Al-Tafsîr. ed. Yûsuf Al-Ghûsy. Beirut: Dar Al-Ma'rifah.

Al-Syinqîthî, M. Al-Amîn ibn Muhammad Al-Mukhtâr Al-Jaknî. (t.t.) Adhwâ' AlBayân fî Îdhâh Al-Qur'ân bi Al-Qur'ân. Mesir: Mathba'ah Al-Madanî.

Al-Thabarî, M. ibn Jarîr. (2001). Jâmi' AlBayân 'an Ta'wîl Âyi Al-Qur'ân. ed. 'Abd Allah ibn 'Abd Al-Muhsin AlTurkî dan Markaz Al-Buhûts wa AlDirâsât Al-'Arabiyyah Al-Islâmiyyah bi Dâr Hijr. Jizah: Dâr Hijr.

Al-Thayyâr, M. ibn Sulaimân ibn Nâshir. (1432 H.). Al-Tafsîr Al-Lughawî li AlQur'ân Al-Karîm. Damam: Dâr Ibn AlJauzî.

Al-'Utsaimîn, M. ibn Shâlih. (1424 H.). Tafsîr Al-Qur'ân Al-Azhîm: Sûrah Yâsîn. Riyadh: Dâr Tsurayyâ.

Âlu Al-Syaikh, S. ibn 'Abd Al-'Azîz ibn Muhammad ibn Ibrâhîm. (2010). Syarh Al-Arba'în Al-Nawawiyyah. ed. 'Âdil ibn Muhammad Mursî Rifâ'î. Riyadh: Dâr Al-' Âshimah. 
Al-Zuhailî, W. (1996). Al-Tafsîr Al-Wajîz: 'Alâ Hâmisy Al-Qur'ân Al-'Azhîm. Damaskus: Dâr Al-Fikr.

Anîs, I. (1976). Dilâlah Al-Alfâzh. Mesir: Maktabah Al-Anjlû Al-Mishriyyah.

Danim, S. (2015). Pedagogi, Andragogi, dan Heutagogi. Bandung: CV Alfabeta.

Ibn Da'jam, A. ibn Sa'id. (2016). Misteri Umur 40 Tahun. Solo: At-Tibyan.

Ibn Da'jam, A. ibn Sa'id. (2019). Misteri Umur 60 Tahun: Menyibak Pernikpernik Usia Kritis di Ambang Kematian.(Sukoharjo: Wacana Ilmiah Press.

Jalghûm, 'A. Ibrâhîm. (2015). Al-Mu'jam Al-Mufahras li Alfâzh Al-Qur'ân AlKarîm Al-Syâmil bi Al-Rasm Al'Utsmânî. Riyadh: Markaz Al-Tafsîr wa Al-Dirâsât Al-Qur'âniyyah.

Karzûn, A. Ahmad. (1999). Wa Balagha Arba'în Sanah: Risâlah Taujîhiyyah li Man Balagha Arba'în Sanah. Jeddah: Dâr Nûr Al-Maktabât.

Karzun, A. Ahmad. (2009). Rahasia Usia 40 Tahun. Jakarta: Daun Publishing.

Majma' Al-Lughah Al-'Arabiyyah. (2012). Al-Mu'jam Al-Wajîz. Mesir: Maktabah Al-Syurûq Al-Dauliyyah.

Naik, Z. (2015). Miracles of Al-Qur'ân \& As-Sunnah. Solo: PT Aqwam Media Profetika.

Nukhbah min Al-'Ulamâ'. (2011). Al-Tafsîr Al-Muyassar. Madinah Munawwarah: Mujamma' Al-Malik Fahd li Thibâ'ah Al-Mushhaf Al-Syarîf.

Rosidin. (2013). Konsep Andragogi dalam Al-Qur'an: Sentuhan Islami pada Teori dan Praktik Pendidikan Orang Dewasa. Malang: Litera Ulul Albab.

Shâliḥ, 'A. Al-Karîm Ibrâhîm. (2016). Ma'âlim Al-Rajûlah fî̀ Al-Qur'ân AlKarîm. Kairo: Syirkah Al-Quds.

Shiddieq, U. M. Dja'far. (2016). Mushaf Tafhim Al-Qur'an. Jakarta: Maktabah Al-Fatih dan Yayasan Darul 'Amal Sukabumi.
Sulthân, N. Muhammad. (1991). Qawâ'id wa Fawâì min Al-Arba'în AlNawawiyyah. Riyadh: Dâr Al-Hijrah.

Suwailim, W. bint 'Abd Al-'Azîz. (2013). Ahkâm Al-Umm fî Al-Fiqh Al-Islâmî. Riyadh: Madâr Al-Wathan.

Suwailim, W. bint 'Abd Al-'Azîz. (2013). Fikih Ibu: Himpunan Hukum Islam Khas Ummahat. Jakarta: Ummul Qura.

Tim Lajnah Pentashihan Mushaf Al-Qur'an. (2012). Kesehatan dalam Perspektif AlQur'an. Jakarta: Direktorat Urusan Agama Islam dan Pembinaan Syariah Kementerian Agama.

Tim Penyelaras Terjemah Al-Qur'an. (2020). Al-Hufaz: Al-Qur'an Hafalan Mudah. Bandung: Cordoba.

Tim Redaksi Kamus Besar Bahasa Indonesia. (2012). Kamus Besar Bahasa Indonesia Pusat Bahasa: Edisi Keempat. Jakarta: PT Gramedia Pustaka Utama dan Departemen Pendidikan Nasional.

Yusrî, Muhammad. (2009). Al-Jâmi' fì Syarh Al-Arba'în Al-Nawawiyyah. Kairo: Dâr Al-Yusr. 
